\title{
Criticisms toward the Job Creation Bill and Ethical Reconstruction of Legislators Based on Prophetic Values
}

\author{
Ilham Dwi Rafiqi ${ }^{{ }^{*}}$
}

${ }^{1}$ Master of Law, Postgraduate Program Universitas Brawijaya, Malang, East Java, 65145, Indonesia
${ }^{*}$ Corresponding author: ilhamdwirafiqi@gmail.com

\begin{tabular}{|c|c|}
\hline Article & Abstract \\
\hline $\begin{array}{l}\text { Article History } \\
\text { Received: Dec 24, } 2020 \\
\text { Reviewed: Dec 29, } 2020 \\
\text { Accepted: Mar 20, } 2021 \\
\text { Published: Mar 22, } 2021\end{array}$ & $\begin{array}{l}\text { Post the issuance of Law Number } 11 \text { of } 2020 \text { concerning Job Creation, the } \\
\text { public paid more attention by continuing to protest and criticize. This response } \\
\text { occurred due to various legislative deviations noticed during the legislative process } \\
\text { of the Job Creation Bill by not adhering to the principles and procedures for the } \\
\text { formation of lans and regulations. The main cause for this deviation is due to the } \\
\text { ethics of the legislators who are not thoroughly compliant and obedient toward the } \\
\text { statutory regulations and social ethics. Legislators' understanding of law and life } \\
\text { tends to be influenced by materialistic-positivistic views that bring forth } \\
\text { consumptive, hedonistic, and secular demeanors and behaviors. On this basis, this } \\
\text { paper tries to criticize and reconstruct the legislators' ethics in law-making. This } \\
\text { study is using a normative juridical method and is supported by a philosophical } \\
\text { approach. The outcomes of this research show that the process in the making of } \\
\text { the Job Creation Bill tends to override the principle of transparency and public } \\
\text { participation with a closed and hasty pattern, so that it is a complete ulterior } \\
\text { hasty agenda that prioritizes the concept of regulating and monitoring only (top } \\
\text { down). A work ethic based on prophetic values that are supported by the ground } \\
\text { principles of a prophetic paradigm that includes humanization, liberation, and } \\
\text { transcendence into a new form of construction to be able to create a better and just } \\
\text { legislative process. }\end{array}$ \\
\hline \multicolumn{2}{|c|}{$\begin{array}{l}\text { (C)2021; This is an Open Access Research distributed under the term of the Creative Commons } \\
\text { Attribution Licencee (https://Creativecommons.org/licences/by/4.0), which permits unrestricted } \\
\text { use, distribution, and reproduction in any medium, provided the original works is properly cited. }\end{array}$} \\
\hline
\end{tabular}

\section{INTRODUCTION}

Public response shown in the form of protests and criticism continues to arise after Law Number 11 of 2020 concerning Job Creation (Job Creation Bill) was officially promulgated on November 2, 2020. Various attempts have been carried out 
by every layer and profession in society to urge the government to evaluate or even revoke the problematic articles in the substance of Job Creation Bill. Several articles contained in the Job Creation Bill are considered to add more problematic clusters such as reduction in labor welfare, the potential in environmental damage ecological disasters, the increase of man-made disasters, educating orientation shifts towards business commodities (investment), up to the weakening of law enforcement (Darmawan, 2020).

The inclusion of problematic articles in the Job Creation Bill is partly due to the deviations in the legislative process that was being carried out. The deviation mentioned can be seen from the beginning of the legal drafting up to the discussion process where the enclosed Job Creation Bill forming process seems hasty and far from the principle of public participation (Safitri, 2020). This condition has led some experts to think that the process in establishing the Job Creation Bill did not comply the legal drafting principles and procedures so that it was not appropriate to process (deadlock).

Putting aside the discussion of COVID-19 disaster matters faced by the country, the legislators seemed to take this as an opportunity of the momentum - instead of dealing with the virus outbreak, they were being assiduous to rush in compiling an omnibus law. The number of protests carried out by citizens did not change the government's consideration and demeanor. Meanwhile, the people's demands seemed to be just a pounding sand of a meaningless action. Public participation is considered an obstacle that must be avoided for the sake of investment and economic development interests. Thus, in the legislative process of the Job Creation Bill, it can be said that the government tends to be "deaf" to the public aspirations.

In addition, the predominantly adopted economic development paradigm tends to have liberal-capitalist nuances that have the potential to arise new problems. On the other hand, this paradigm can induce a setback in the practice of the development process that has been developing by using an inclusivity approach with a sustainable development model. The dominant-centralized party system that is trying to revive will also lead to a centrally focused concentration of power, which on the other hand can injure the decentralization principle that has been constructed in this country.

The Job Creation Bill is the first law in Indonesia that was formed based on the omnibus law method. This method has a decent goal because it aims to solve the problem of over-regulated and disharmony regulations in Indonesia (Busroh, 2017). However, the initial momentum for the government to implement the omnibus law through the Job Creation Bill as a starting point for the regulatory reformation was actually injured by irregularities. The inaugural application of the omnibus law in Indonesia has a more negative impression on society and bad precedent for the dynamics of the state administration. 
The main cause of the deviation in the legislative process of creating the Job Creation Bill was due to the legislators' work ethic that is not thoroughly compliant and obedient towards the statutory regulations and social ethics. Legislators with the immensity of knowledge ironically often use their aristocracy intelligence to perform maneuvers that include "hidden interests" under the regulations designed to expedite electoral interests, not to mention other immoral acts such as corruption and breaches of discipline. Such demeanor and behavior are influenced by a paradigm that seeks to purify values which is none other than the positivistic paradigm of modern science. Syed Muhammad Naquib Al-Attas stated that the problem in human civilization nowadays is the hegemony and the domination of westernmodern science that negate absolute truth and results in chaos of values. Humans are then considered to be the center of all life, while nature was created only to meet human needs (anthropocentric) (Nasr, 1989). In line with this view, Fritjof Capra also stated that humans are currently living in a "turning point" period, where the inability of humans to see life as a whole causes a crisis in the intellectual, moral, and spiritual dimensions of human itself (Suteki, 2011). Capra even believed that western culture had been annihilated because it was exaggerating in eulogizing the ratio (Capra, 2009).

The modern scientific paradigm not only predisposes scientific civilization that is empirically and rationally limited in a theoretical concept, but also affects the practical ethics of human life which Rusli Muhammad said can bring forth the materialistic, pragmatic, hedonistic, and secular demeanors (Muhammad, 2013). This kind of view often provokes the legislators to make a regulation that is exploitative and repressive.

The Job Creation Bill is a concrete example of this hegemony. The occurrence of irregularities in the legislative process is carried out in the form of an intransparent law-making process and unaccommodated public participation in the preliminary evidence that this law is full of hidden interests. Therefore, this paper will try to reveal and criticize these deviations, by reviewing and analyzing the legal drafting process in the making of the Job Creation Bill. Due to the arising entity of political power and hegemony of the established paradigm (status quo), this paper will present a new discourse that is considered more humane and divine to criticize and reconstruct the current ethics of the legal drafting process.

This paper is presented with the aim of not only filling in the drought in the study of law. Using a prophetic paradigm in studying legal issues will certainly cause polemics and question marks among academics and legal practitioners because this paradigm is still in the stage of searching for an identity. However, it is precisely this kind of academic culture that needs to be developed. By offering the concept of a prophetic paradigm into legal science, this paper is expected to specifically contribute 
to improving the practice of drafting legislation and be able to contribute theoretically to the realm of legal science.

\section{METHOD}

The research method used is normative legal research, namely research that examines statutory regulations, legal theorems, legal principles, and doctrines that develop and relate to the issues discussed (Ali, 2016). This legal research is carried out to invent arguments, theories, and new concepts as a prescription of what the right solution should be carried out to solve the problem at hand. The answers expected in this legal research are right, appropriate, inappropriate, or wrong. So that the outcomes obtained in this research will already contain appropriate values (Marzuki, 2009).

For this reason, the approaches used in this research are the statutory approach especially Law Number 11 of 2011 concerning the Formation of Laws dan Regulations (as amended by Law Number 15 of 2019), conceptual approaches such as the concept of drafting laws and regulations, public participation, ethics of state administrators, as well as being supported by a philosophical approach to explore the fundamentals assumptions of the prophetic paradigm and link its relevance to the development of the legislators' professional ethics. The legal materials used consist of primary legal materials in the form of legislation and regulations consisting of laws, official records, or the treatises of the legal drafting process, as well as verdicts. Moreover, the secondary legal materials consist of research outcomes, scientific articles, journals, law dictionaries, and various other products that have informative values to substantiate this research. The literature study is used as the technique of accumulating legal materials. Those legal materials that have been processed are then analyzed with analytical and interpretative methods so that a new legal argument and prescription are generated.

\section{RESULTS AND DISCUSSION}

\section{Criticism towards the Legal Drafting Process of The Job Creation Bill}

The government's efforts to compile the omnibus law as a method that has been developed in common law countries into the Indonesian legal system need to be tried with a thorough research study. This needs to be done considering that the implementation of the omnibus law in the originating country has also proven to have many problems (Massicotte, 2013). The transplantation of a foreign legal system into a national legal system cannot be simply applied without proper adjustments with the considerations of the pros and cons of it in accordance with the nation's conditions and needs. Robert B. Seidman in his 1970 scientific research even provided a commentary of the adoption of law as "the law of non-transferability". Seidman stated that it is impossible to transfer a law that is divergent from one 
country to another just because this law has its own social structure or often said to be "a peculiar social of life" (Suteki, 2018). Adriaan Bedner argues that the process of adapting various systems outside the national legal system into the national legal system in a country always goes through a process of adjustment, therefore Adriaan said that the more appropriate term to use is not legal adoption but "legal amalgamation" (Bedner, 2017). This misunderstanding has led to the application of the omnibus law through the Job Creation Bill to run inefficiently and has drawn extensive public criticisms.

We cannot disavow that every legal drafting agenda will always get the political influence based on certain political conditions within a country that there is a tug of war between the political power itself which Duverger refers to as "een neerslag van politieke machtsverboudingen" (sediment from the political power reciprocity within the society) (Rahardjo, 2010). Therefore, aside from being referred to as a legal product, laws are also often referred to as political products.

Nevertheless, this does not mean that a legal drafting process must capitulate and obsequious towards political powers without paying attention to the needs of the community. A legal drafting process must also revert to its essence, as John Locke stated that laws are made with the aim of providing goods to the people or containing the elements of public interests (Anggono, 2014). To be more profound, Jeremy Bentham refers legal drafting process as art, namely the art of finding ways to actualize "the true good of the community-the greatest happiness of the community". The legal drafting process must comply with the principles and procedures regulated in the drafting of statutory regulations to be able to make laws that can achieve these objectives (Rahardjo, 2010).

The Job Creation Bill as a law that initiates the outset point of regulatory reform using the omnibus law method unfortunately tends to override this aim. The legal drafting process of the Job Creation Bill tends to be cloistered and forced to rush, causing the public aspirations and values to not be proportionally and properly aggregate and accommodated. It is said to be cloistered because as we already know from April 20, 2020 up to October 3, 2020, the deliberation of the Job Creation Bill was carried out by 64 prompt meetings without embroiling all parties of interest. The government has indeed requested public aspirations, but the people referred by the government refer to investors and not general civilians such as laborers or farmers. The legal academic manuscript of the Job Creation Bill was also not published in time and there was also a tug of war which ambiguous for the public. With the largescale of material substances regulated under the Job Creation Bill, doubled with the current emerging situation of COVID-19 pandemic, the government should have been able to postpone the legal discussion instead of imposing this law to be immediately passed. Therefore, normatively, the legal drafting process of the Job Creation Bill has violated the participatory principle and the principle of public 
transparency as regulated under Law Number 12 of 2011 concerning The Establishment of Legislative Regulations (which then updated through Law Number 15 of 2019).

Regarding the participatory principle, Article 96 of Law Number 12 of 2011 concerning The Establishment of Legislative Regulations has guaranteed that every citizen has the right to be involved in the legal drafting process. It states that the people have the right to provide aspirations vocally and/or written during the legal drafting process through public hearings, work visits, social outreach, seminars, workshops, and/or public discussions. To facilitate the citizens in giving oral and/or written aspirations, each Bill must be easily accessible for the public.

The existence of public participation in the legal drafting process is essential to prevent the abuse of power within the laws. In addition, the existence of public participation also illustrates the existence of a harmonious relationship between the citizens and the legislators within the government that is expected to provide beneficial legal drafting in a responsive and long-lasting goal to be an effective law for the good of the people in all levels of society (Yuliandri, et.al., 2014).

Public participation in the legal drafting process can be carried out when the principle or public transparency is also applied, the two principles do have a very tight knot. The principle of public transparency has a meaning that in the legal drafting process starting from planning, drafting, discussing, ratifying, or stipulating, and promulgating, it has to be transparent and open to the public. When the legal drafting process is carried out in a transparent and open manner, the public will have room to deliver their aspirations. On the other hand, if the legal drafting process is carried out in a cloistered and hasty manner, public aspirations cannot be accommodated which also shown as a form of denial of democratic principles. This last condition is reflected in the legal drafting process of the Job Creation Bill.

The statement that the legislative process of the Job Creation Bill is declared non-participatory and open is not an assumption based solely on cynicism and pessimism but is a rational judgment based on facts and evidence. Various experts in legal institutions stated the same thing, such as the Faculty of Law, Gadjah Mada University with its Policy Paper on Critical Notes on the Job Creation Bill which questioned the basic principles contained (Sigit Riyanto, et.al., 2020), the Indonesian Center for Law and Policy Studies and the Indonesian Legal Aid Foundation which stated that The Job Creation Bill is flawed in the procedure (Admin PSKH, 2020), the Indonesian Center for Environmental Law (ICEL) also considers that the legislative process of the Job Creation Bill is closed and various other views are the same individually from legal experts (Feby Ivalerina, et,al., 2020). All views have the same judgment, namely that the Job Creation Bill process does not apply the principles of participation and openness. 
Thus, if analyzed constructively, it can be seen as having a certain pattern in the legislative process of the Job Creation Bill that does not reflect the ideal legal drafting process in accordance with the guidance of lawmaking. The non-participatory legal drafting process leads to the use of the concept of being limited to regulating and supervising (top-down), where the will of the authorities and entrepreneurs is prioritized and accommodated in the Job Creation Bill (Harefa \& Alhusain, 2020). The top-down concept does not provide adequate space for the public to deliver their aspirations so that there is no "discourse of interest" in it. The citizens in this case only serve as the object of the rules made (humans for law). However, the substances and the form of law must be accepted with all kinds of consequences of injustice. That kind of legal drafting pattern can often produce repressive legal products according to Moh. Mahfud MD (Mahfud MD, 2014). The pattern of the legal drafting process for the Job Creation Bill can be described through the following chart:

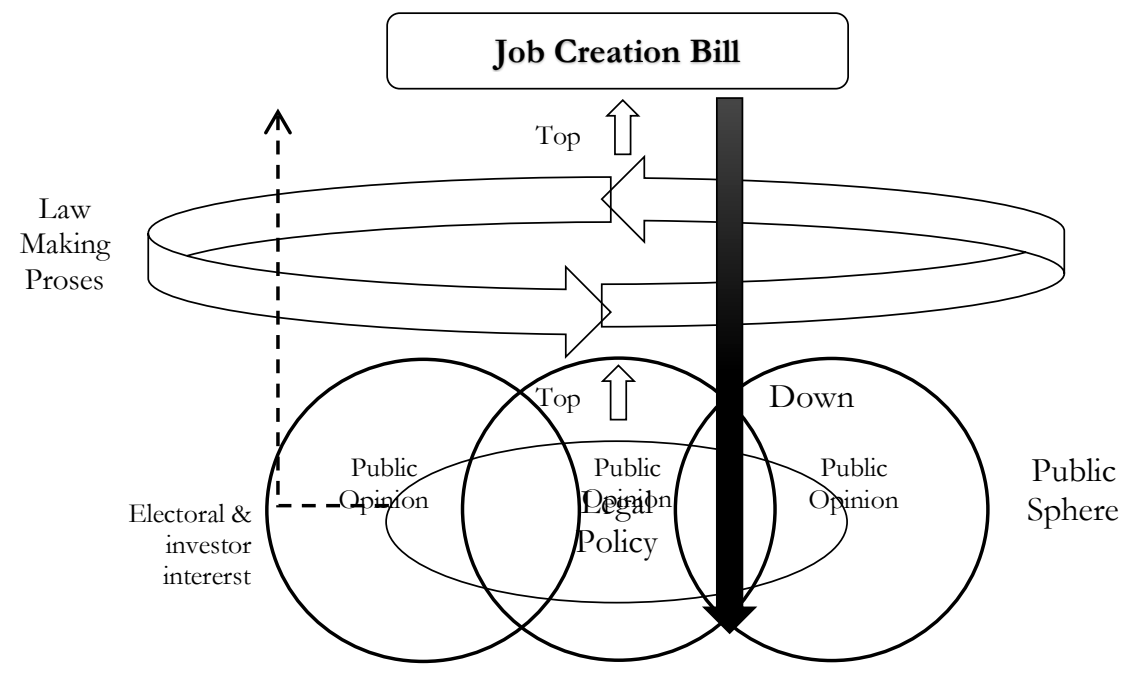

Chart. 1. The Pattern of the Job Creation Legal Drafting

The legal drafting process of the Job Creation Bill which does not comply with the procedures and the principles of public participation is a contrary towards the ideal principle of the ideal legal drafting process. The process of forming good laws and regulations is rooted to a socio-rational consensus. F. Budi Hardiman quoting Jürgen Habermas view stated that the consensus in question an intersubjective collective agreement, in which legislators must set aside their own interests or other interests that are detrimental toward the society. Habermas stated that a legal drafting process in the legal system is the true locus of social integration. Therefore, those who take part in a legal drafting process are advocated to leave their role as subjects of private law and their role as citizens (staatsbürger) to take over the perspective as a part of dependent legal community member voluntary (Hardiman, 2009). 
It is recognized that the government's enthusiasm to actualize economic progress through productive and conducive investment is indeed an important thing. However, that does not mean that this law is only formed to fulfill the value of certainty to cater to the interests of investors only in the name of legal investment. Legislators see that seeing that guaranteed protection of investor ownership and low social and environmental transaction costs will lead parties to adopt the most efficient solutions to address risks (Coase, 1960). The illustration is that if there is the pollution it will be resolved between the pollution company and the community victims of pollution through a cheap trough solution. This is what is meant by why the Job Creation Bill is said to facilitate investment at the expense of long-term risks. What the government perpetrates can be assumed as a form of "naivety" and full of manipulations. The maxim to increase public welfare and employment is only a camouflage to cover up the malicious compromises of the existing political oligarchs and businessmen.

Scientific studies carried out through Academic Papers in the preparation of the Job Creation Bill do not guarantee that this law is formed by procedures and principles, because it is realized that if a bill is included in the plenary session discussion that occurs is a tug of political interest rather than discourse scientific. The arguments compiled in the Academic Paper of the Job Creation Bill are relatively based on statistical data which is still weak and untested are also the reasons why this law has received a lot of protests from the public (Sigit Riyanto, et.al., 2020). Even if seen in the reference, the Academic Paper on the Job Creation Bill does not look like the Academic Paper in general, because it only refers to 9 books, 5 journal papers, and 1 research result. The draft of the Job Creation Bill which was to be passed also caused polemic because there were various types of drafts and each had different pages. As an umbrella or principal law that is the first to use the omnibus law method, the legislation process for the Job Creation Bill should be carried out according to procedures based on legal provisions and become an example of a good description of the legislative process.

The legal drafting process of the Job Creation Bill once again reinforces the image that the law is often used as a tool of authority. Law as a tool of power has a negative connotation that plays a role in manipulating, debauchery, and shaping regulation in a dishonest way. In fact, normalization as Michel Foucault puts it is the product of a series of performances at play - the legal system is an important public arena through which the state attempt-through manipulation of symbols, image, and ideas-to legitimize a social order that most people find alienating and inhumane (Hutchinson in Awaludin Marwan, 2010).

All legal regulations relating to the process of establishing statutory regulations starting from Article 28 of the 1945 Indonesian Constitution, Article 96 of Law Number 12 of 2011 concerning the Establishment of Legislative Regulations, and 
various other supporting regulations have guaranteed the standing of public participation. Therefore, the ideal construction of a legal drafting process basically has a democratic character that places public participation as an important condition (conditio sine quo non) (Dinata, 2019). What is required by the law is also required by the logic of social appropriateness that concludes public participation as an important role in the legal drafting process. Any rule of law that is made responsive and in favor of the people will tend to bring prompt compliance - the law is accepted where it is enforced.

At this point, it can be understood that the problem in the legal drafting process fundamentally lies more in the subject of the law-makers themselves (legislators). Demeanors and behaviors that tend to hedonism, pragmatism, materialism, and secularism can often actually sway decent laws into bad ones. Intellectual intelligence is often misused - being used to commit digressions in the making of laws. Being lawful is not enough to just prioritize a manner of rationality above all else, but it is way more than that, which needs to be supported by "spiritual intelligence". This combination will form a manner of determination, empathy, dedication, and commitment towards society so that people's needs can be framed suitably.

\section{The Ethical Reconstruction of Legislators Based on Prophetic Values}

Scientists and philosophers ranging from Socrates (399 BC), Plato (427-347 BC), Aristotle (384-322 BC) to Cicero (106-43 BC) have long highlighted that the inadequacy of a leader in carrying out a public mandate is considered as a violation. One of the indications of the inadequacy of state administrators mentioned before is the abuse of power, such as breaking the law and ignoring ethics. Plato argues that what's meant by a good government is a government whose practice is based on the law (Habibi, 2014). Meanwhile, Cicero argues that good governance is a government that pays attention to civil society. Because civil society is a manifestation of political ethics which political ethics itself roots from various entities supported by two basic elements, namely religion and living law (Azhary, 1992).

The deviation committed by the legislators in the legal drafting process of the Job Creation Bill is one of the many violations in state administration that have been committed by the Indonesian government. The legislators referred to in this case are the drafters of the Job Creation Bill which includes the government in the executive function and the House of Representatives of the Republic of Indonesia in the legislative function. As previously explained, the basis for the occurrence of deviations in the legal drafting process of the Job Creation Bill is consumptive, materialistic, hedonic, and secular ethical demeanors. This kind of demeanor resulted from a modern-positivistic view of esoteric knowledge and life that is only worth the mundane values. These demeanors and behaviors must always be criticized so that the state's goals for citizen welfare can be actualized with certainty. 
The emergence of various new viewpoints in response to this, of course, both are looking for truth in essence. Also, that each approach has its own epistemology that distinguished based on the method taken and what kind of validity to achieve (Dimyati, 2014). As a paradigm that was born during the postmodern era, the prophetic paradigm is a new paradigm that is considered relevant to provide solutions to these problems, especially problems related to deviant actions or abuse of power that are committed by state administrators (Kuntowijoyo, 1991).

The prophetic paradigm affirms its position as a communitarian idea such as the critical theory that aims for the interests of emancipatory praxis which collectively asserts that knowledge is not separate from interests, also that every theory is not separate from praxis (Absori, Wardiono, Rochman, 2015). Apart from going inward for emancipation, the prophetic paradigm also functions outward to survive the war - ghazwul fikr or intellectual aggression against the enemies of materialism and secularism in the modern world that can lead to clutter and destruction (Kuntowijoyo, 2018). This prophetic paradigm has a scientific basis from the inside of Social Prophetic Science developed by Kuntowijoyo that became one of many integrative models between esoteric knowledge and religion, as well as a response and criticism towards the secularism of the social-humanities science that has dominated the mindsets of scientists in general, which also become a solution to the existing problems of modernity (Dimyati, et.al., 2015). The epistemological reorientation is carried out towards the "mode of thought" and "mode of inquiry" by assuming that esoteric knowledge is not only obtained based on an empirical ratio apocalypse (Kuntowijoyo, 1991).

The prophetic paradigm does not then become an exclusive paradigm. This paradigm has the value of religiosity that can not only be applied in social science problem solving but also problems in the legal discipline itself. Both good personal and institutional responses were commenced by initiating a discourse on "prophetic law" which began to develop and be developed by Heddy Shri Ahimsa-Putra (UGM), Syamsudin, Jawahir Thontowi, Artidjo Alkostar, Busyro Muqoddas (UII), Khudzaifah Dimyati, Absori, Kelik, Ridwan, Saepul Rochman (UMS), Jazim Hamidi (UB), and some other parties for example. What is meant by the science of prophetic law is not only based on the validity at the level of haqq alyakin that is contained in the Al-Quran and Hadith, but also based on the validity obtained by human capabilities and potentials through reflections, reasonings, and discourses that have developed within the society. Humans explore, cultivate, and formulate esoteric knowledge with the aim not only for the knowledge itself but also for virtue and significance with the blessings and love of Allah (Absori, 2017). Therefore, the basis of epistemology - the modalities of the prophetic paradigm in the acquisition of knowledge (the seeking for validity) and including the law-making agenda that 
includes empirical senses, ratio, qolbu (intuition), and apocalypse that each of which is integrally related.

The presence of prophetic law is not an exaggeration or even considered as a thought that is too far-fetched. Prophetic law exists and can be approved within the society because basically, the constitution provides the space for it. The space mentioned is being resembled under the first precept of Pancasila, the fourth paragraph in the Preamble of the 1945 Constitution, up to the Article 29 paragraph (1) of the 1945 Constitution which recognizes "The One and Only Almighty God" as the spiritual spirit - a transcendental that is closely related to prophetic law. Various statutory regulations have also contained this value. For example, in the legal drafting process based on Law Number 12 of 2011 concerning the Establishment of Laws and Regulations, it is stipulated that every bill drafting of statutory regulations is mandatory to include the phrase "By the Grace of God Almighty" in its preamble. These provisions mentioned before should not only become semantic rules (picturesque in the literature) but must internalize and externalized in every legal drafting process and regulatory outcome.

With the same vigor - by carrying a particular mission for the development of legal science, a prophetic paradigm is developed to provide solutions to various legal problems and to liberate the materialistic-positivistic way of thinking and acting. The idea of the liberation itself is deliberately directed towards the professional ethics of legislators who currently tend to have the orientation of materialistic-positivistic demeanor although they are all important political agents who can determine where the policy direction has to be applied after all.

The comprehensiveness of the prophetic paradigm, starting from the scientific basis, the philosophical basis, to the fundamental assumptions, all are rooted from the values contained in the Al-Quran Surah Ali Imron: 100. The legal drafting process based on the prophetic paradigm contains the principles of humanization (ta'muruna bil ma'ruf), liberation (tanhauna anil munkar), and transcendence (tu'minuna billab) (Jayanuarto, 2018). These three principles then developed into new values that are trying to be instilled within the professional ethics of the legislators, so that the legal drafting process can create decent laws and can be approved by the people.

In the prophetic paradigm, the value of transcendence is seen as key and decisive value. This means that whether in every scientific, government administration or daily activities, the transcendence value must always be manifested in the form of recognition and obedience. The recognition and obedience in the legal drafting process is manifested through various acts and awareness within a work ethic that is not only mundane in the value but also ukhrawi (spiritual). Heddy Shri Ahimsa-Putra has divided the work ethic which contains these two values into 4 (four) work ethics namely devotion, scientific, humanitarian, and universal work ethics. The work ethics 
of the prophetic value in the legal drafting process can be delineated in the following chart (Ahimsa-Putra, 2013):

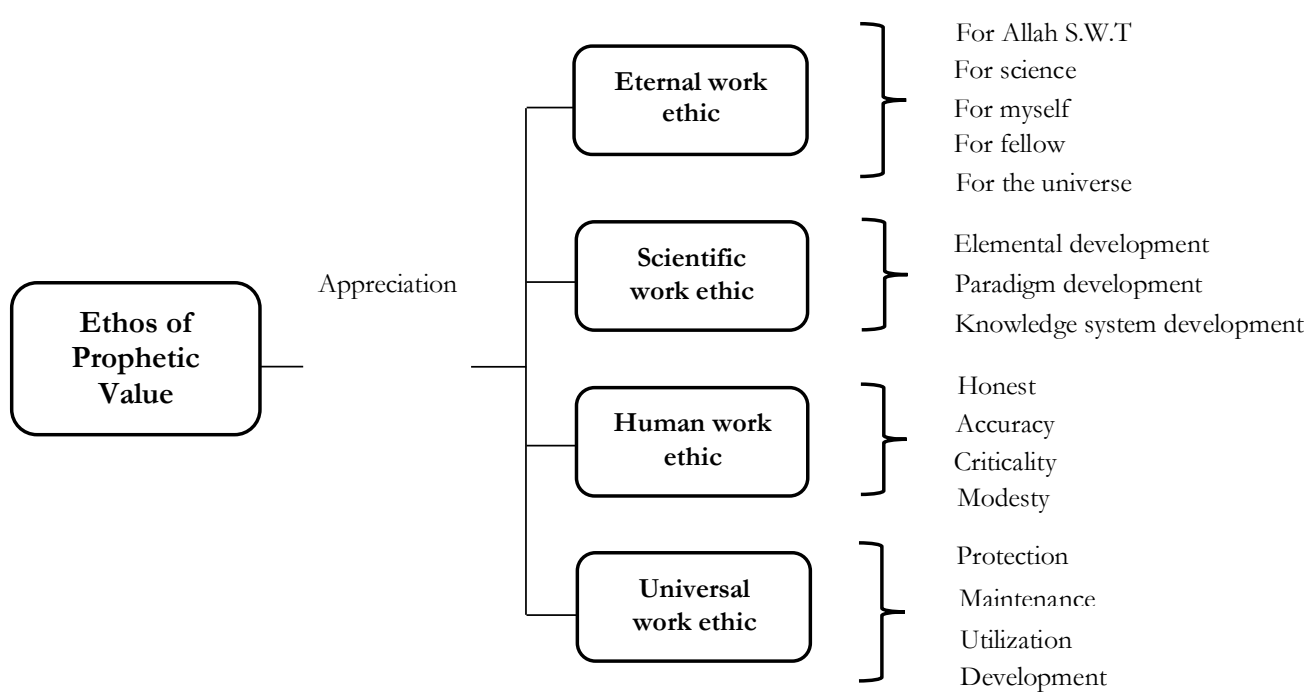

Chart. 2. Prophetic value-based work ethics

The professional ethics of the legislators who currently tend to have the orientation based on the mundane will only construct consumptive, materialistic, hedonistic, and secular manners and demeanors. The legal drafting process is considered solely to mundane bliss, such as in the legal drafting process of the Job Creation Bill that the law was formed to cater the value of certainty to serve the interest of investment exclusively. Such ethical construction is necessary to be rectified and put back into its true nature as a human being, namely through the manifestation of professional ethics of prophetic values. Legislators who have a prophetic value-based work ethic will consider that every legal product that is made reflects on a form of worship that will be held accountable for each action they are taking so that a manner of honesty, thoroughness, criticism, and humility is formed. The aim of making legal products is not in favor of the investor or electoral political interests, but for something more extensive, namely for the sake of virtue, people welfare, and seeking the blessings of Allah.

This prophetic value-based work ethic can be carried out optimally if the three principles of the prophetic paradigm consisting of humanization, liberalism, and transcendence are also applied. Humanization in the legal drafting process refers to the aim to oppose the conditions of dehumanization, collective aggressiveness, and solitude (privatization-individuation) (Kuntowijoyo, 2018). Dehumanization in the legal drafting process occurs due to dominations or principle-errors that are applied. Legal products are often established on the basis of the right to develop only so that anything can be done as long as it is for the benefit of development on that basis. The most important factor in the law-making that the law has the value of certainty to cater and serve economic development, as well as accelerating investment matters. 
In this condition, humanity is sometimes dependent on economic-industrial interests. Privatization and individuation supported by technological and industrial advances have resulted in an increase in collective aggression. Collective aggression in the legal drafting process can be seen in the form of compromise between the authority of political oligarchs and businessmen to accommodate their interests so that their personal interests can be surreptitiously included within the articles in a certain law. This possibility is likely to occur due to the zeal of legal development that functions more to serve than just becoming an imperative life guide.

The establishment of laws that override the principles of sustained development or future survival tends to be influenced by consumptive, hedonistic, and pragmatic manners - the most important goal to obtain is the current bliss and benefits. Such an attitude is created from the ontological design of the anthropocentric paradigm which assumes that humans are the center of all life and that nature was created only to meet human needs (Akib, 2014). This view has been tried to be reoriented by the prophetic paradigm by presenting "theoanthropocentric humanism". The recognition of theoanthropocentric humanism can provide awareness for legislators to be able to uplift and restore human dignity through God's way which leads to lawmaking that is not solely based on the essence of law itself but for the sake of virtue, people welfare, and seeking the blessings of Allah.

Liberalism in the legal drafting process has the meaning of liberating the system from the interests of oligarchs, capitalists, authoritarianism, and all other interests that are contrary to the value of consensus-mutual interests. Liberalism in this context is not only carried out in the field of abstract humanitarian thought or morality but is also applied to empirical realities such as the embodiment in state administration ethics. Therefore, liberalism also aims at emancipatory and communitarian praxis as well as liberation theory. With liberalism, the domination of political power in the legal drafting process seeks to be neutralized (not in the sense of eliminating political activity entirely), because the law that is seen as a dependent variable will always be predisposed by political situations and authorities. Liberalism in the legal drafting process seeks to place the discourse of interest in a process that has more humane and divine values. Legislators are the important agents to prevent the occurrence of nahi munkar (infamy) demeanor, to ensure that the legal drafting process is in line with the corridors and prioritizes the benefit of the people.

Humanization and liberalism are inseparable from the principle of transcendence. At the same time, transcendence has become the basis for providing a direction to which and for what the purposes of humanization and liberalism are carried out. Laws that have transcendent values aim at justice based on the truth of the power of Allah which aims to achieve bliss in the hereafter. Transcendence as the core of the prophetic paradigm does not orient only to the spiritual culmination (mystical-sufistic), but continues to strive on earth as human existence as a "Caliphate" 
to always engage in virtue (amar ma'ruf) and prevent the infamy demeanor (nabi munkar). Humans who are involved in mundane matters while not being separated from their transcedent ties or divine consciousness are referred to as prophetic humans (bomo-propheticus) (Iqbal, 2018).

A prophetic value-based work ethic that is supported by the fundamental principles of a prophetic paradigm will become a new construction to create a better legal drafting process. The legal drafting process that is supported by a prophetic value-based work ethic places religion and divine values as the main pivot while still paying attention to datums and social needs. The culmination value of transcendence is expected to optimize the spirituality of legislators so that they have commitment and responsibility towards God. The epistemology of transcendental law does not depend on the ability of rational reasoning by oneself, but also optimizing the highest intelligence namely spiritual intelligence - spiritual quotient (SQ). With a spiritual capital and opposing the barriers of formalism, the potential to obtain essential validities (justice based on the true power of Allah) will have a greater chance to be obtained, because indeed it is only humans who can mobilize all the power to unite everything that differs - different for the sake of achieving unity and validity (actions sunt suppositorum). By predicting the prophetic value, the establishment of laws can be formulated up to the decent term.

\section{CONCLUSION}

Criticism of the legal drafting process of the Job Creation Bill aims to reveal and criticize the septum of legislative deviations committed. The legal drafting process of the Job Creation Bill which tends to be cloistered and hasten causes the social values and aspirations of the citizens unable to be proportionally aggregated and accommodated. The legislative pattern used in the Job Creation Bill uses a concept that is limited to regulating and supervising (top-down), where the interests of the rulers and entrepreneurs are prioritized and accommodated. In the name of investment, the law was then formed only to fulfill the interest of investment matters only. The citizens in this case only play a role as the object of the laws made, however, the substances and form of the law itself must be approved with all of its consequences of injustice. This law drafting process pattern often creates repressive legal products.

The current status quo which illustrates that legislators tend to pursue mundane values with consumptive, materialistic, hedonistic, and secular manners are reoriented and reconstructed by using prophetic values so that they can apply as their true essence. The prophetic paradigm opposes the conditions of dehumanization, collective aggression, and solidity (privatization- individuation) in the legal drafting process. The anthropocentric view that dominates the professional ethics of the legislators is reoriented by presenting a theoanthropocentric recognition of 
humanism (humanization-ta'muruna bil ma'ruf). The legal drafting process based on the prophetic paradigm carries out the liberalism (liberation-tanhauna anil munkar) system from the interests of oligarchs, capitalists, authoritarianism, and all other interests that are contrary to the value of consensus-mutual interests. By applying humanization and liberalism based on transcendence in creating a work ethic that reflects on prophetic values, the establishment of law can be formulated to the decent term by upholding the values of virtue, the people welfare, and seeking the blessings of Allah.

\section{REFERENCES}

Absori, Kelik Wardiono, S. Rrochman. (2015). Hukum Profetik: Kritik Terbadap Paradigma Hukum Non-Sistematik. Yogyakarta: Genta Publishing, 12.

Absori. (2017). Pemikiran Hukum Transendental Dalam Konteks Pengembangan Ilmu Hukum Indonesia. In Transendensi Hukum: Prospek dan Implementasi, Yogyakarta: Genta Publishing in collaboration with Program Doktor (S3) Ilmu Hukum Sekolah Pascasarjana Universitas Muhammadiyah Surakarta, 7-19. http:/ / eprints.ums.ac.id/57714/1/Transenden Lengkap.pdf

Ahimsa-Putra, H. Heddy Shri. (2013). Paradigma Profetik: Sebuah Konsepsi. In Syamsudin (ed.), Ilmu Hukum Profetik: Gagasan Awal, Landasan Kefilsafatan dan Kemungkinan Pengembangannya di Era Postmodern, Yogyakarta: FH UII Press, 62.

Akib, Muhammad. (2014). Pergeseran Paradigma Penegakan Hukum Lingkungan: dari Mekanistik-reduksionis ke Holistik-ekologi. Masalab-Masalab Hukum, 43 (1), 125131. https://doi.org/10.14710/mmh.43.1.2014.125-131

Harefa, Mandala. \& Alhusaim, Avhmad Sani. (2020). Pembentukan Omnibus Law dalam Upaya Meningkatkan Investasi. Parliamentary Review, II (1), 15.

https://berkas.dpr.go.id/puslit/files/parliamentary_review/Parliamentary Review-II-1-M-2020.pdf

Ali, Zainuddin. (2016). Metode Penelitian Hukum. Jakarta: Sinar Grafika, 24.

Anggono, Bayu Dwi. (2014). Perkembangan Pembentukan Undang-Undang Di Indonesia. Jakarta, Konstitusi Press, 23.

Azhary, M. Tahari. (1992). Negara Hukum (Ke-1). Jakarta: Bulan Bintang, 26.

Bedner, Adriaan. (2017). Amalgamating Environmental Law in Indonesia. In J. Arnscheidt \& \& J. M. O. B. Van Rooij (Eds.), Lawmaking for Development: Explorations into the Theory and Practice of International Legislative Projects (Vol. 4, Issue 2, pp. 447-471). Leiden University Press. https://doi.org/10.1017/als.2017.21

Busroh, Firman Freaddy. (2017). Konseptualisasi Omnibus Law Dalam Menyelesaikan Permasalahan Regulasi Pertanahan. Arena Hukum, 10 (2), 227-250. https://doi.org/10.21776/ub.arenahukum.2017.01002.4

Capra, Fritjof. (2009). The Turning Point: Titik Balik Peradaban Sains, Masyarakat, dan Kebangkitan Kebudayaa (M. Thoyib (ed.)). Yogyakarta: Jejak, 1-39

Coase, Roland. (1960). The Problem of Social Cost. Law \& Economics, Vol. III, 1-44.

Darmawan, Agus. (2020). Politik Hukum Omnibus Law Dalam Konteks Pembangunan Ekonomi Indonesia. Indonesian Journal of Law and Policy Studies, 1 (1), 13. https://doi.org/10.31000/ijlp.v1i1.2655

Dimyati, Khudzaifah. (2014). Pemikiran Hukum: Konstruksi Epistemologis Berbasis Budaya 
Hukum Indonesia. Yogyakarta: Genta Publishing, vi.

Dimyati, K., \& Kelik Wardiono, Ridwan, S. R. (2015). Pemikiran Transendental Model Profetik. In Hukum Transendental: Pengembangan dan Penegakan Hukum Di Indonesia, Yogyakarta: Genta Publishing in collaboration with Program Doktor (S3) Ilmu Hukum Sekolah Pascasarjana Universitas Muhammadiyah Surakarta 2 (20), 71 85.. https://publikasiilmiah.ums.ac.id/bitstream/handle/11617/9683/5. Khudzaifah.pdf?sequence $=1$ \&isAllowed $=\mathrm{y}$

Dinata, Ari Wiryana. (2019). Mekanisme Partisipasi Publik dalam Proses Pembentukan Peraturan Perundang-Undangan. In Menggagas Arah Kebijakan Reformasi Regulasi di Indonesia: Prosiding Forum Akademike Kebijakan Reformasi Regulasi 2019. Yayasan Studi Hukum dan Kebijakan Indonesia (YSHK), 68. www.pshk.or.id

Feby Ivalerina, et. al., (2020). Hukum Dan Kebijakan Lingkungan dalam Poros Percepatan Investasi: Hukum dan Kebijakan Lingkungan Dalam Poros Percepatan Investasi, 1. https://icel.or.id/kertas-kebijakan/hukum-dan-kebijakan-lingkungan-dalamporos-percepatan-investasi-catatan-terhadap-wacana-omnibus-law-ciptalapangan-kerja/

Habibi, Nur. (2014). Praktik Pengawasan Etika Dewan Perwakilan Rakyat Republik Indonsia. Jurnal Cita Hukum, Vol. II No. 1, 40. http://journal.uinjkt.ac.id/index.php/citahukum

Hardiman, F. Budi. (2009). Demokrasi Deliberatif: Menimbang Negara Hukum dan Ruang Publik dalam Teori Diskursus Jürgen Habermas. Kanisius, 66.

Hutchinson, Allan. C. (2010). Critical Legal Studies In Awaludin Marwan, Teori Hukum Kontemporer: Suatu Pengantar Postmodernisme Hukum. Yogyakarta: Rangkang Education, 28.

Iqbal, Muhammad. (2018). The Reconstruction Of Religious Thought In Islam. California: Stanford University Press, 385. http://www.archipress.org/docs/pdf/iqbalreconstruction.pdf

Jayanuarto, Rangga.. (2018). Hukum Dan Keadilan Berparadigma Profetik. In (Absori, et) Pemikiran Hukum Profetik: Ragam Paradigma Menuju Hukum Berketuhanan.

Yogyakarta: Ruas Media, 35.

https://publikasiilmiah.ums.ac.id/bitstream/handle/11617/10301/PEMIKIRA N HUKUM PROFETIK.pdf?sequence $=1$ \&isAllowed $=\mathrm{y}$

Kuntowijoyo. (1991). Paradigma Islam: Interpretasi Untuk Aksi (Priyono (ed.)). Bandung: Mizan, 168, 289.

Kuntowijoyo. (2018). Muslim Tanpa Masjid Idi Subandy Ibrahim (ed.)). Yogyakarta: IRCiSoD, 112, 388-391.

Marzuki, Peter Mahmud. (2009). Penelitian Hukum (ke-5). Jakarta: Kencana Prenada Media Group, 35.

Massicotte, Louis. (2013). Omnibus Bills in Theory and Practice. Canadian Parliamentary Review, 36 (1), 16-17.

MD, Moh. Mahfud. (2014). Politik Hukum Di Indonesia, (ke-6). Jakarta: Rajawali Pers, 22.

Muhammad, Rusli. (2013). Remarks inside In Syamsudin (ed.), Ilmu Hukum Profetik: Gagasan Awal, Landasan Kefilsafatan dan Kemungkinan Pengembangannya di Era Postmodern. Yogyakarta: FH UII Press, vi.

Nasr, Sayyed Husein. (1989). Knowladge and Sacred. New York: State University of 
New York Press, 33-34. http://traditionalhikma.com/wpcontent/uploads/2015/03/Knowledge-and-the-Sacred-The-GiffordLectures.pdf

PSKH, Admin. (2020). Proses Legislasi Serampangan Hasilkan Cacat Formil UU Cipta Kerja. https://pshk.or.id/publikasi/siaran-pers/proses-legislasi-serampanganhasilkan-cacat-formil-uu-cipta-kerja/

Rahardjo, Satjipto. (2010). Sosiologi Hukum: Perkembangan Metode Dan Piliban Masalah (Cetakan II). Yogyakarta: Genta Publishing, 140, 137.

Safitri, Dini. (2020). Omnibus Law RUU Cipta Lapangan Kerja dalam Perspektif Komunikasi Pembangunan Partisipatif. Jurnal Dialog Kebijakan Publik, 32(July), 39_49. file://C:/Users/ASUS/Downloads/JurnalDialogKebijakanPublikNo.32_Kem kominfo.PDF

Sigit Riyanto, et. al., (2020). Kertas Kebijakan: Catatan Kritis Terbadap Uu No 11 Tabun 2020 Tentang Cipta Kerja. In Sell Journal (Vol. 5, Issue 1) 1, 25. https://rispub.law.ugm.ac.id/wpcontent/uploads/sites/1049/2020/11/Kertaskebijakan-analisis-UU-Cipta-Kerja-FH-UGM-5-November-2020-rev-1.pdf Suteki. (2011). Rekam Jejak Pemikiran Hukum Progresif Satjipto Rabardjo In (Myrna A. Safitri (ed.)) Satjipto Rahardjo dan Hukum Progresif: Urgensi dan Kritik. Jakarta: Epistema Institute dan HuMa, 30.

Suteki. (2018). Hukum Progresif: Hukum Berdimensi Transendental dalam Konteks Keindonesiaan. In Hukum Transendental: Pengembangan dan Penegakan Hukum Di Indonesia, Yogyakarta: Genta Publishing in collaboration with Program Doktor (S3) Ilmu Hukum Sekolah Pascasarjana Universitas Muhammadiyah Surakarta, 3. https://publikasiilmiah.ums.ac.id/bitstream/handle/11617/9667/1. Suteki.pdf?sequence $=1 \&$ is Allowed $=\mathrm{y}$

Yuliandri, et.al. (2014). Laporan Akbir Pengkajian Hukum Tentang Partisipasi Masyarakat Dalam Penentuan Arah Kebijakan Prioritas Penyusunan Peraturan Perundang-Undangan, Jakarta: Pusat Penelitian dan Pengembangan Sistem Hukum Nasional Badan Pembinaan Hukum Nasional, Kementerian Hukum dan Hak Asasi Manusia Republik Indonesia, 7-8.

https: / $/$ www.google.co.id/url?sa $=t \& r c t=j \& q=\& e s r c=s \&$ source $=w e b \& c d=2 \& c$ $\mathrm{ad}=$ rja\&uact $=8 \& \mathrm{ved}=2 \mathrm{ahUKEwjsqJ} 3 \mathrm{msqLj}$ AhUKQo $8 \mathrm{KHeK} 2 \mathrm{BrgQFjABegQI}$ AxAC\&url=https $\% 3 \mathrm{~A} \% 2 \mathrm{~F} \% 2 \mathrm{Fwww}$.bphn.go.id $\% 2 \mathrm{Fdata} \% 2 \mathrm{Fdocuments} \% 2 \mathrm{Fla}$ p.akhir_pengkajian_hukum_prioritas_perundang-undangan.pdf\&usg=AOvVaw 